Relations industrielles

Industrial Relations

\title{
Renegade Lawyer: The Life of J. L. Cohen by Laurel Sefton \\ MACDOWELL, Toronto: University of Toronto Press, 2001, 385 pp., ISBN 0-8020-3513-2.
}

\section{Judith McCormack}

Volume 58, numéro 1, hiver 2003

URI : https://id.erudit.org/iderudit/007381ar

DOI : https://doi.org/10.7202/007381ar

Aller au sommaire du numéro

Éditeur(s)

Département des relations industrielles de l'Université Laval

ISSN

0034-379X (imprimé)

1703-8138 (numérique)

Découvrir la revue

Citer ce compte rendu

McCormack, J. (2003). Compte rendu de [Renegade Lawyer: The Life of J. L. Cohen by Laurel Sefton MACDOWELL, Toronto: University of Toronto Press,

2001, 385 pp., ISBN 0-8020-3513-2.] Relations industrielles / Industrial Relations, 58(1), 162-165. https://doi.org/10.7202/007381ar

Tous droits réservés (C Département des relations industrielles de l'Université Laval, 2003
Ce document est protégé par la loi sur le droit d'auteur. L’utilisation des services d'Érudit (y compris la reproduction) est assujettie à sa politique d'utilisation que vous pouvez consulter en ligne.

https://apropos.erudit.org/fr/usagers/politique-dutilisation/ 
documents qui se penchent sur « les problèmes de la main-d'œuvre vieillissante », l'ouvrage retient toutefois l'attention par la vigueur de son style et la conviction de l'auteur qu'il est crucial de maintenir en emploi les travailleurs vieillissants dans des conditions convenables. Sicker associe étroitement ce qui attend les travailleurs vieillissants avec les transformations du marché du travail ; point de vue tout à fait pertinent mais très rare. L'approche centrée sur les «problèmes particuliers » de cette catégorie de main-d'œuvre, pour laquelle on envisage des mesures particulières ou antidiscriminatoires, sans les situer dans le dynamisme des mutations du monde du travail, est plus fréquente. La conclusion est cependant décevante. Aucune synthèse à la fin ne permet de refermer ce livre en ayant une vision claire des principales idées défendues par l'auteur.

Pour mener à bien ses démonstrations, Sicker a consulté une somme considérable de matériaux. Il fait preuve d'une bonne capacité d'analyse, mais demeure trop proche des variations conjoncturelles et est trop tributaire des analyses des auteurs qu'il cite abondamment. Il abuse des citations et même de citations de citations, souvent trop longues. Malgré sa connaissance d'autres sources, plus étoffées, Sicker s'alimente surtout à des sources journalistiques, rapidement désuètes (quotidiens, hebdomadaires, communiqués de presse) ainsi qu'à la littérature grise. Les exemples qu'il documente avec des statistiques deviennent rapidement répétitifs, faute d'un cadre d'analyse qui en dégagerait le sens plus nettement. Ses sources sont presque exclusivement américaines et datent surtout de 1995 à 1999. Un peu mince pour qui vise à écrire un ouvrage sur l'économie politique du $\mathrm{XXI}^{\mathrm{e}}$ siècle. Au terme de la lecture, ses objectifs politiques concernant les travailleurs vieillissants n'ont que l'allure de vœux pieux, faute de perspectives constructives et non seulement polémiques.

Auteur prolifique sur des sujets très variés, militant de l'American Association of Retired Persons (AARP), le plus important groupe de pression pour les personnes âgées aux États-Unis, qui fait beaucoup pour la reconnaissance du droit au travail et à l'emploi des personnes vieillissantes, Sicker nous offre un ouvrage de vulgarisation plutôt qu'une contribution scientifique inédite.

L'ouvrage demeure néanmoins une lecture intéressante pour des publics préoccupés par la question du maintien en emploi des travailleurs vieillissants, pour alimenter et développer des interventions collectives ou des choix personnels, mais d'un apport limité pour celles qui enseignent, étudient ou font de la recherche dans le domaine.

HÉLÈne DAVID

Université de Montréal

\section{Renegade Lawyer: The Life of J. L. Cohen}

by Laurel Sefton MACDowELL, Toronto: University of Toronto Press, 2001, 385 pp., ISBN 0-8020-3513-2.

Lawyers occupy an odd place in North American popular culture, functioning as both heroes and villains with equal verisimilitude. Our ambivalence about them in this regard is unusual. For most occupations, we know where we stand, at least in popular culture terms. We love doctors, for instance, and we hate drug dealers. When it comes to lawyers, however, for some reason we are able to toggle easily between the image of a lawyer as a mercenary shark, and the lawyer as a champion of the underdog, not to mention a host of images in between these poles. Our television and movie screens are virtually crowded with lawyers: washed-up lawyers, neurotic waif lawyers, corrupt lawyers, 
alcoholic lawyers, sexpot lawyers, ruthless lawyers, noble lawyers, incompetent lawyers, keen lawyers, obsessed lawyers, novice lawyers, idealistic lawyers, and many more. There seems to be no end to our thirst for lawyer stories, and the line between our fictional lawyers and our real ones often becomes blurred. We make stories of our real lawyers (witness Johnny Cochran and Marcia Clark), while our fictional lawyers often seem disconcertingly life-like.

All this is by way of introducing a lawyer and his story, in the form of Laurel Sefton MacDowell's biography of J. L. Cohen. MacDowell has created a comprehensive picture of a brilliant labour lawyer who spent years building a unique professional career, only to see it destroyed as a result of a disastrous mistake.

Cohen was a labour lawyer before there was labour law in Ontario, or at least before the advent of modern industrial relations legislation. He was exceptionally bright, dedicated and hardworking, with the result that he left his mark on much of the labour law which emerged before and during the Second World War, including minimum employment standards, unemployment insurance, and collective bargaining legislation. Although his main focus was the representation of unions and the pursuit of industrial democracy, he was also a civil libertarian before there was a Charter of Rights, and his clients included unionists, poor people, Communists, Jehovah's Witnesses and wartime internees. MacDowell gives us a skilful and layered portrait of a prickly man who was fiercely committed to his work and to his clients, and who was both admired for his expertise, and despised by the Toronto legal establishment.

Cohen was born in England to Lithuanian Jewish parents, who joined the migration of eastern European Jews to Toronto in the early 1900's. His family life included weekly political discussion groups with socialist, union, or Zionist themes, and Cohen, the eldest of six, was encouraged to do well in school by his supportive father. When he was thirteen, however, his father fell through ice in the course of his travels in Northern Ontario and drowned. This was devastating for Cohen, who then became the breadwinner of the family. He cobbled together various sources of income, worked and took correspondence courses, and eventually became a lawyer by articling at a law firm for two years while attending lectures.

MacDowell does an excellent job of evoking the political and social climate of the day, pointing out that among other things, Cohen was entering a profession that was rife with anti-Semitism. Jews were not hired by established firms, and generally had to start their own practices, serving their own communities and supplementing their incomes with non-legal work. Her description of this is highlighted by the startling fact that Bora Laskin, then equipped with an LL.M. from Harvard, and later to become Chief Justice of the Supreme Court of Canada, was refused a position by every single law firm he contacted.

MacDowell builds up a perceptive and complex picture of Cohen, tracing his convictions to his personal and professional experiences, and providing extensive insight into both how his times shaped him as a person, and how he shaped his times. One particularly poignant example of the relationship between his personal life and his work is reflected in his involvement in a high profile murder case in regard to two union organizers who disappeared during a bitter lumber strike near Port Arthur. In an eerie echo of his father's death, the organizers were later found drowned, officially as a result of falling through the ice. MacDowell suggests that Cohen's interest in the case was at least in part related to this connection.

Because of the degree of Cohen's engagement in the events of the day, the 
narrative of his life is also a narrative of some of the struggles of the labour movement in the thirties and forties, as well as the defiance of the Communist Party with respect to Depression-era attempts to muzzle free speech, the wartime legal abuses with respect to the civil liberties of internees, and the reluctant development of modern labour legislation. Legally speaking, this is not a pretty picture. Public gatherings were prohibited or broken up by police, and demonstrators were roughed up or arrested for vagrancy, obstruction and unlawful assembly. Communist Party members were harassed, and the Toronto Police Commissioners prohibited their meetings and threatened to cancel the licenses of those who rented space to them. Eventually, the Communist Party was banned outright, along with Jehovah's Witnesses, the Finnish Organization of Canada and other organizations deemed subversive. (Those who feel Canada rises above the jingoism of the U.S. will find it humbling to be reminded that Jehovah's Witnesses were prosecuted for not saluting the Canadian flag, not to mention for possessing socalled "illegal literature.")

Members of banned organizations were also subject to internment, and due process for internees received short shrift. Cohen had difficulty gaining access to interview his clients, was not provided with the charges against them, and could not adequately prepare his cases. A number of prominent union officials were also interned amid allegations that the government was using the process to interfere with strikes and other union activities. In general, the book serves as a useful reminder for anyone with misplaced nostalgia: that the good old days were merely the old days.

Cohen's primary focus, however, was the labour movement, and MacDowell makes it clear that his fingerprints are all over labour law. He lobbied for legislation, drafted legislation, wrote on labour policy, brokered legislative deals between constituencies, created key collective agreement language, and sat on the National War Labour Board. For the labour lawyer, Cohen's activities provide a sobering insight into the period which essentially gave birth to Canadian labour legislation. The ferocity of employer opposition, the anti-union sentiments of the government (highlighted by the use of "Hepburn's Hussars" to break up the 1937 General Motors strike in Oshawa) and the degree of determination and stamina required to extract basic protections are all carefully detailed by MacDowell in serviceable, if uninspired prose.

Indeed, the price paid to obtain collective bargaining legislation makes it all the more disturbing that some of these provisions have recently been repealed by neo-conservative governments, only to be replaced by legislation which is rather unsubtly designed to hamper union organizing and to facilitate unfair labour practices by employers. With Cohen's era freshly in view, it is difficult to avoid the impression that twenty-first century labour legislation has taken a frog leap backward into time. Of course, this impression is not limited to labour law; the description of politicians in the thirties purging "chisellers" from relief roles has a certain plus ca change, plus c'est la meme chose quality as well.

For Cohen, the price paid for the development of labour legislation also entailed significant personal cost. He worked sixteen-hour days for years, suffered from a number of phobias, and by the summer of 1945, was experiencing nervous and physical exhaustion. $\mathrm{He}$ was also drinking heavily at times, and was probably addicted to sedatives. This set the stage for his downfall, triggered by the Guenard incident.

Elizabeth Guenard was hired as a secretary by Cohen in 1945, and they began a stormy affair almost immediately, marked by public quarrelling. In 
November, they were staying at a hotel in Kirkland Lake, while Cohen presented a brief he had written for the Mine Mill union for its convention. Screams from their hotel room in the middle of the night brought hotel staff to their door, where they observed that Guenard's face was scratched, and her lips puffed. A doctor who examined her found bruises and a broken nose. A few days later, Guenard returned to work at Cohen's office.

In late December, the police approached Guenard, drove her to a station and questioned her for hours about the incident. She signed a statement in which she alleged that Cohen had hit her in the face, breaking her nose. Later she recanted, accusing the police of forcing the statement out of her. In the meantime, Cohen was charged with assault, and a second charge which was eventually dropped.

A Toronto lawyer who was a friend of Cohen's reported that a group of mine-owners was behind the charge, and there is no doubt that Cohen had made a number of enemies. The Attorney General who decided to prosecute him had been aggressively cross-examined by Cohen several months previously (Cohen had suggested he was a liar), and it seems clear that the prosecution itself was odd in a number of respects. The Attorney General presented a bill of indictment against Cohen, an unusual procedure which eliminated the possibility of a dismissal at a preliminary hearing, and it appears that there was some manoeuvring by the Crown with respect to the selection of a judge in what turned out to be a sensational case. Cohen was convicted and sentenced to six months in prison, again, a surprising sentence in the circumstances. Subsequently, he was disbarred, and although he was eventually reinstated, both his career and his health were ruined, and he died a year later at the age of fifty-three.

MacDowell's painstaking accounts of Cohen's trial, appeal, and the disciplinary proceedings which followed make it difficult to avoid the conclusion that Cohen did indeed assault Guenard, but also that he would not have been prosecuted or disbarred if he had not been a radical, a self-made man of working class origins, a Jew and the subject of some professional envy. MacDowell describes his vulnerability in this regard, and suggests that this was compounded by his transgression of a masculine code of chivalry in mistreating a young woman.

The most compelling element of Cohen's life story, however, is not his persecution, which was indeed appalling, but almost banal in its details. The book's central purchase comes from the story of a man who was both a tireless advocate for the downtrodden and disenfranchised, and a deeply flawed person. The adversity in his life appears to have fuelled both his tenacity and his neuroses, reinforcing his commitment while at the same time creating fault lines in his character. This conundrum is compelling precisely because it means that Cohen cannot be made into a cardboard hero (or a cardboard villain, for that matter). Instead, his life reflects all the complexity, turmoil and chaos of an authentic human being.

JUDITH MCCORMACK University of Toronto 